\title{
Problems of epitypification in morphologically simple green microalgae: a case study of two widespread species of Klebsormidium (Klebsormidiophyce- ae, Streptophyta)
}

\author{
Fabio RINDI ${ }^{1}$, David RYŠÁNEK ${ }^{2} \&$ Pavel ŠKALOUD ${ }^{2 *}$ \\ ${ }^{1}$ Dipartimento di Scienze della Vita e dell'Ambiente, Università Politecnica delle Marche, Via Brecce Bianche, \\ 60131 Ancona, Italy \\ ${ }^{2}$ Department of Botany, Faculty of Science, Charles University of Prague, Benátská 2, CZ-12801 Prague, \\ Czech Republic; * Corresponding authore-mail: skaloud@natur.cuni.cz
}

\begin{abstract}
The extensive genetic cryptic diversity revealed by molecular studies in many green microalgae has caused great uncertainties in the circumscription of some species described on strictly morphological grounds. These uncertainties should be resolved by obtaining molecular data from type materials, but this procedure is not feasible in many species because the type specimens are illustrations, or too small or poorly preserved to obtain DNA sequence data. In these situations, the selection of an epitype is often a mandatory requirement to define the identity of a species and establish unambiguously its position in molecular phylogenies. In this study we investigated the identity of two widespread species of Klebsormidium (Streptophyta), K. flaccidum and $K$. nitens, which were recently epitypified by Mikhailyuk and colleagues. We collected several specimens of these algae from the type localities and the original habitats of these two species, for which we examined morphology in the field material and in culture, and obtained sequences of the $r b c \mathrm{~L}$ gene. On the basis of the original descriptions, we conclude that the designation of the epitype of $K$. flaccidum was correct, whereas the epitype of $K$. nitens (which consists of material collected tens of thousands of $\mathrm{km}$ from the type locality) was most probably incorrect. We discuss the implications of these decisions for the classification of Klebsormidium and, more generally, the importance of the correct choice of epitype material for the taxonomy of green microalgae.
\end{abstract}

Key words: epitypes, Klebsormidium, molecular phylogeny, morphology, taxonomy, type locality

\section{INTRODUCTION}

In recent decades, the introduction of DNA sequence data in studies of systematics and taxonomy has revolutionized the classification of all groups of algae. The impact of these methods has been particularly strong on algal groups with simple morphologies, resulting from an evolutionary history characterized by high levels of morphological homoplasy. The use of molecular data has greatly advanced our understanding of the genetic diversity of these organisms and has been of substantial help for species circumscription, particularly in taxa where morphology is strongly affected by phenotypic plasticity related to environmental conditions. In numerous cases, however, the contrasting scenarios drawn by morphological and molecular data have been source of major nomenclatural problems that for some taxa have not yet been resolved.

Green microalgae living in freshwater and terrestrial habitats (belonging to the Chlorophyta and
Streptophyta lineages; LELIAERT et al. 2012) are perhaps the most apposite group to exemplify these difficulties. These organisms have a simple morphology that is preferable to three main different habits: single cells; uniseriate filaments, either branched or not; few-celled colonies, of various shape (Rindi 2011). Based on molecular data produced in the last 20 years, it is now clear that rampant morphological convergence has frequently occurred during the evolution of these algae, producing almost identical morphologies in unrelated species (Huss et al. 1999; Krienitz \& Bock 2012; FučíkovÁ et al. 2014; KRIENITZ et al. 2015). Several genera, apparently well-defined from a morphological point of view, were recovered as polyphyletic or paraphyletic in molecular phylogenies (e.g., Chlorella BeIs. - Huss et al. 1999; Dictyosphaerium NäGELI - BocK et al. 2011; Pediastrum Meyen - BuchHeim et al. 2005; Printzina R.H.Thompson et D.E.Wujek and Trentepohlia Mart. - Rindi et al. 2009; Trebouxia Puym. - ŠKaloud \& Peksa 2010). In the recent past this called for major 
taxonomic reassessments that resulted in the description of numerous new taxa; in particular, the splitting of a genus into multiple genera, or a species into multiple species, frequently occurred (e.g., Huss et al. 1999; Bock et al. 2011; AllewAERT et al. 2015; ŠKaloud et al. 2015). A common problem arising in these cases is to link correctly Linnaean names with clades recovered in molecular phylogenies (VERBRUGGEN 2014), which is a fundamental requirement in order to apply correctly names of species and genera. The only definitive way to establish such a link is to obtain sequences from the type specimen or strain (the only one to which a name is unambiguously associated), and establish its placement in molecular phylogenies. In general, this is not a problem for green microalgae described in the last 10 15 years, for which the description is usually based on both morphological and molecular data, and sequences from type strains are frequently available. However, many common green microalgae were described by early botanists (e.g., Linnaeus 1753, 1759; AgardH 1824; KÜTZING 1843, 1849; NÄGELi 1849) based only on morphological characters. For these, apart for a few fortuitous exceptions in which the original culture is still available (e.g., Chlorella vulgaris BEIJ., the type species of the genus Chlorella; KRIENITZ et al. 2015) or the type is a relatively large and well conserved specimen (e.g., Prasiola crispa (Lightfoot) Kützing, Moniz et al. 2012), the type specimen/strain cannot be used for DNA extraction and sequencing, usually because the material is either too scanty or is an illustration. Problems of this type have the potential to lead to a situation of taxonomic paralysis and can be resolved only with the designation of a carefully selected epitype, the morphology of which agrees in full with the original protologue and the type specimen.

The genus Klebsormidium P.C. SILVA, MatTOX et W.H. BLACKWELL includes 21 species of green algae distributed in a wide range of terrestrial and freshwater habitats (ETTL \& GÄRTNER 1995; LOKHORST 1996; ŠKALOUd 2006), classified in the family Klebsormidiaceae, order Klebsormidiales (Streptophyta). Morphologically, Klebsormidium is characterized by uniseriate unbranched filaments formed by cells containing a single parietal chloroplast with a pyrenoid, reproducing only by biflagellate zoospores produced in undifferentiated cells and released through an ostiole in the cell wall (ETTL \& GäRTNER 1995; LOKHORST 1996; Guiry \& Guiry 2015). These features make members of this genus readily recognizable. However, it has long been acknowledged that identification at species level is complicated by the scarcity of useful morphological characters and the phenotypic plasticity that affects some of them. In the last 10 years, molecular data on Klebsormidium have been produced in plentiful amounts (Novis 2006; MiKhaILYuK et al. 2008; RINDI et al. 2008, 2011; KAPLAN et al. 2012; KARSTEN et al. 2013; ŠKALOUD \& Rindi 2013; ŠKALOUD et al. 2014; Mikhailyuk et al. 2015; RYŠÁNEK et al. 2015, 2016a, 2016b), revealing a great deal of genetic diversity and the paraphyly of the genus as defined on morphological basis, due to the inclusion in it of Interfilum $\mathrm{R}$. Chodat, a genus that shares with Klebsormidium many ultrastructural and developmental features (MiKHAILYUK et al. 2014) but consists of packet-like mucilaginous colonies (MikhaiLYuK et al. 2008, 2014). This has greatly confused the circumscription of some species, including the type species Klebsormidium flaccidum (Kütz.) P.C. Silva, Mattox et W.H. Blackwell. The original description of this alga (as Ulothrix flaccida KüTZ.; KütZING 1849) is brief and does not provide important morphological details. So, the morphological circumscription of the species has been largely shaped by descriptions provided by subsequent authors (RABenhorst 1868; Hansgirg 1886; De Toni 1889; Hazen 1902; Mattox \& Bold 1962; Printz 1964; RamanaTHAN 1964; EtTl \& GÄRTNER 1995; LOKHORST 1996). Sometimes, descriptions provided by different authors disagree with regard to some morphological characters, and only very few authors (e.g., LOKHORST 1996) appear to have examined the type material; seemingly, none of them tried to re-collect this alga from the original type locality and habitat (cobbled streets in Strasbourg, France). In molecular phylogenies, strains identified as $K$. flaccidum are scattered in many different clades, making this species polyphyletic (RINDI et al. 2008, 2011; Š́KALOUd \& Rindi 2013; ŠKALOUD et al. 2014; RYŠÁNEK et al. 2015). The same situation applies to another common species of Klebsormidium, $K$. nitens (Menegh. In Kütz.) LoKhorst. An additional complication in this case is that the type locality was not designated. The original description (MENEGHINI IN KüTZING 1849: 349) does not make any mention of the original collection site and the specimen designated by LOKHORST (1996) as type does not provide any information that may be of help in this regard.

These uncertainties required a reassessment of the identity of both $K$. flaccidum and $K$. nitens based on the designation of epitypes for which molecular data are available. In a recent study, MikhaiLyuk et al. (2015) resolved this problem proposing epitypes for several Klebsormidium species, including $K$. flaccidum and $K$. nitens. To epitypify the two species, these authors selected strains isolated and investigated by LOKHORST (1996), who provided the most recent monographic treatment of the genus. However, the work of LOKHORST (1996) was published at a time when molecular data for Klebsormidium were not available and none of the strains selected were isolated from type localities or presumptive collection areas (i.e., France and Italy). In fact, the strains SAG 2307 (epitype of K. flaccidum) and SAG 13.91 (epitype of $K$. nitens) were obtained from samples collected respectively in Niederkruechten, Germany, and Tekoa, New Zealand.

Recently, we had an opportunity to make collections of terrestrial algae in the type localities of $K$. flaccidum and $K$. nitens. We collected there samples 
of Klebsormidium from habitats corresponding to the original descriptions and we selected among them strains in morphological agreement with the original protologues. In this study we characterize morphologically and genetically these strains, comparing them with the to the epitypes proposed by MikHAILYUK et al. (2015). Based on this comparison, we discuss some general implications for epitypification of morphologically simple green microalgae.

\section{Material and Methods}

Collections and cultivation. A population of $K$. flaccidum was collected by PŠ on 28 May 2014 in Strasbourg, France, the type locality of Ulothrix flaccida. A mixed sample was collected by scraping several green crusts from an old stone block pavement, in la Place du Marché Gayot (48.5828 N, $7.7531 \mathrm{E})$. The samples were placed in plastic sampling vials, and transferred to the laboratory. Search for authentic Klebsormidium nitens was made by FR on 15 November 2014 in the botanical garden of Padua, Italy (45.399 N, $11.880 \mathrm{E})$, a site that can be considered presumptive type locality of Ulothrix nitens Menegh. IN Kütz. (see Discussion). Samples were collected by scraping green crusts from flowerpots (the type of habitat mentioned in the original description), margins of pools and old walls. The samples were placed in plastic Zip- loc bags and mailed to PŠ in sealed envelopes. In the laboratory, the samples were spread on Petri dishes with agarized BBM medium (BIschoff \& Bold 1963), and cultivated at $25^{\circ} \mathrm{C}$ under a constant photon irradiance of $34 \mu \mathrm{mol} . \mathrm{m}^{-2} \cdot \mathrm{s}^{-1}$ provided by cool fluorescent tubes (Philips Master TL5 HE 21W/840, Royal Philips Electronics, Amsterdam, the Netherlands). Algal microcolonies grown up after 5-10 weeks were transferred repeatedly to fresh Petri dishes. After three changes of each isolate to fresh Petri dishes, the obtained cultures were observed to be unialgal by examination under a light microscope. Unialgal stock cultures of Klebsormidium were maintained in liquid BBM, under the conditions described above.

DNA extraction, sequencing, and phylogenetic analyses. DNA was isolated according to the protocol published by RYŠÁNEK et al. (2015), and stored at $-20^{\circ} \mathrm{C}$. Sequences of the $r b c \mathrm{~L}$ gene, which encodes the large subunit of ribulose-1,5bisphosphate carboxylase/oxygenase, were obtained by polymerase chain reaction (PCR) amplification with a Touchgene Gradient cycler (Techne, United Kingdom). The $r b c \mathrm{~L}$ gene was amplified by using the newly designed primer KF590 (5'-GAT GAA AAC GTA AAC TCT CAG C-3') and the primer rbcL-KR2 (5'-GGT TGC CTT CGC GAG CTA-3'; ŠKALOUD \& RINDI 2013). Each 20-ml reaction for PCR was conducted as described by RYšÁnEK et al. (2015). The PCR protocol followed ŠKALOUD \& RINDI (2013). Sequencing reads were assembled and edited using the SeqAssem software (HEPPERLE 2004).

Table 1. Cell dimensions of investigated Klebsormidium strains.

\begin{tabular}{|c|c|c|c|c|c|c|c|}
\hline \multirow[t]{2}{*}{ Strain } & & \multicolumn{3}{|c|}{ cell width $(\mu \mathrm{m})$} & \multicolumn{3}{|c|}{ cell length $(\mu \mathrm{m})$} \\
\hline & & average & $\min$ & $\max$ & average & $\min$ & $\max$ \\
\hline \multirow{3}{*}{ S201 } & overall dimensions & $7.4 \pm 0.7$ & 6.4 & 8.8 & $9.6 \pm 3.6$ & 4.3 & 15.7 \\
\hline & fresh cultures & $6.8 \pm 0.2$ & 6.4 & 7.1 & $11.8 \pm 3.5$ & 5.4 & 15.7 \\
\hline & nutrient-depleted cultures & $8.0 \pm 0.6$ & 6.6 & 8.8 & $7.4 \pm 2.0$ & 4.3 & 10.0 \\
\hline \multirow{3}{*}{ S202 } & overall dimensions & $6.3 \pm 0.7$ & 5.4 & 7.9 & $12.6 \pm 3.5$ & 5.3 & 20.8 \\
\hline & fresh cultures & $5.9 \pm 0.3$ & 5.4 & 6.5 & $13.7 \pm 3.5$ & 7.7 & 20.8 \\
\hline & nutrient-depleted cultures & $6.9 \pm 0.6$ & 6.0 & 7.9 & $10.9 \pm 2.9$ & 5.3 & 15.7 \\
\hline \multirow{3}{*}{ S203 } & overall dimensions & $7.0 \pm 0.5$ & 5.8 & 8.0 & $12.0 \pm 3.3$ & 6.1 & 18.1 \\
\hline & fresh cultures & $6.7 \pm 0.4$ & 5.8 & 7.4 & $11.3 \pm 3.2$ & 6.1 & 18.0 \\
\hline & nutrient-depleted cultures & $7.4 \pm 0.4$ & 6.9 & 8.0 & $13.7 \pm 2.9$ & 7.5 & 18.1 \\
\hline \multirow{3}{*}{ F1B } & overall dimensions & $6.8 \pm 0.4$ & 6.1 & 7.7 & $9.4 \pm 2.4$ & 5.3 & 13.2 \\
\hline & fresh cultures & $7.0 \pm 0.3$ & 6.4 & 7.7 & $8.7 \pm 2.4$ & 5.3 & 12.6 \\
\hline & nutrient-depleted cultures & $6.4 \pm 0.2$ & 6.1 & 6.8 & $10.7 \pm 1.8$ & 6.4 & 13.2 \\
\hline \multirow{3}{*}{$\mathrm{F} 3 \mathrm{C}$} & overall dimensions & $6.9 \pm 0.5$ & 6.0 & 7.7 & $10.6 \pm 4.1$ & 5.4 & 22.7 \\
\hline & fresh cultures & $7.1 \pm 0.3$ & 6.6 & 7.7 & $9.0 \pm 2.5$ & 5.4 & 14.6 \\
\hline & nutrient-depleted cultures & $6.5 \pm 0.4$ & 6.0 & 7.3 & $13.0 \pm 4.8$ & 8.0 & 22.7 \\
\hline \multirow{3}{*}{ F8B } & overall dimensions & $7.4 \pm 0.5$ & 6.4 & 8.4 & $9.3 \pm 2.4$ & 5.5 & 14.1 \\
\hline & fresh cultures & $7.7 \pm 0.3$ & 7.1 & 8.4 & $8.6 \pm 2.2$ & 5.7 & 13.1 \\
\hline & nutrient-depleted cultures & $6.8 \pm 0.2$ & 6.4 & 7.2 & $10.5 \pm 2.3$ & 5.5 & 14.1 \\
\hline
\end{tabular}




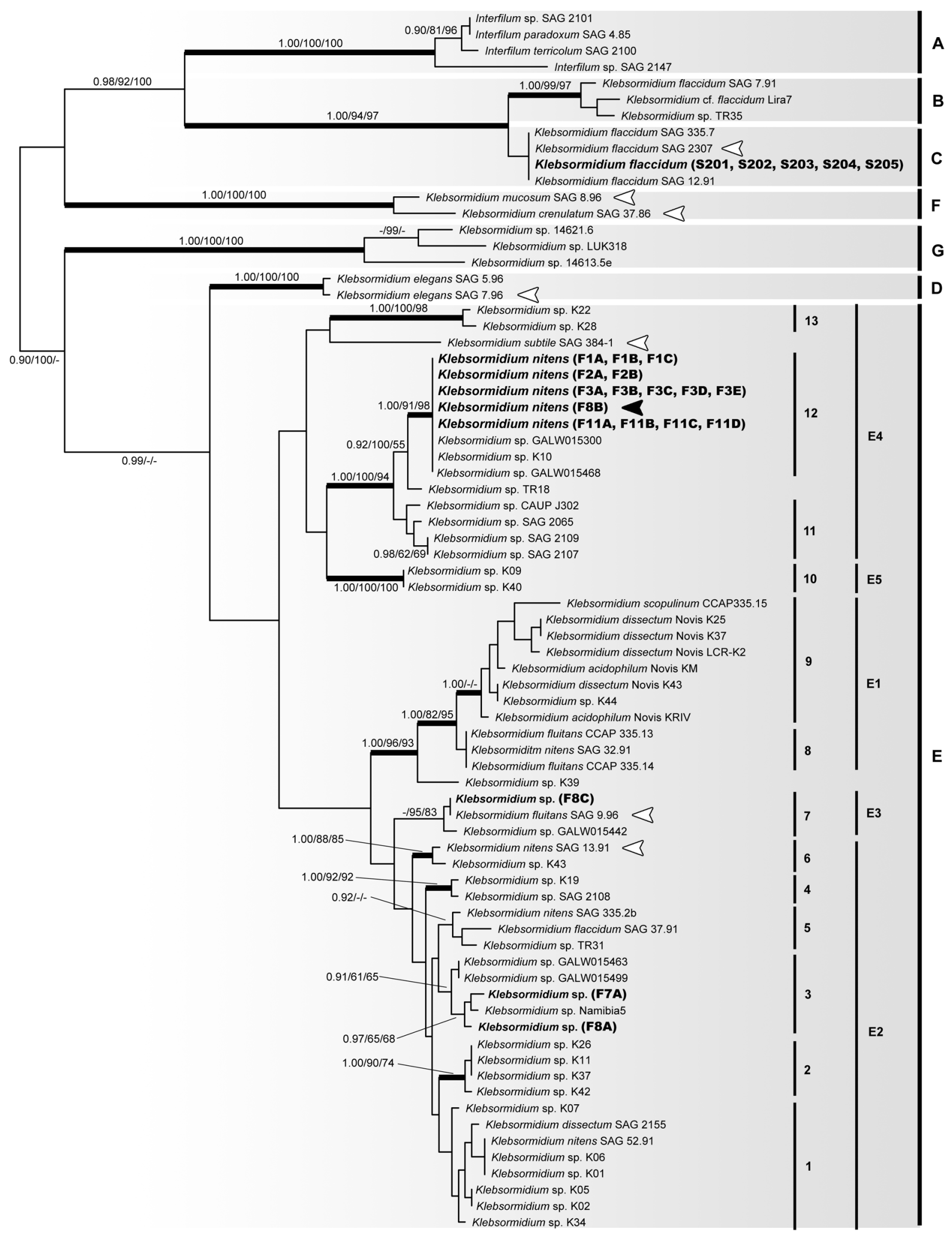

Fig. 1. Phylogenetic tree obtained from Bayesian analysis based on $r b c \mathrm{~L}$ dataset, showing the position of investigated Klebsormidium strains and their relatives. Values at the nodes indicate statistical support estimated by MrBayes posterior node probability (left), maximum likelihood bootstrap (middle) and maximum parsimony bootstrap (right). The clade numbering (A-G, 1-13) follows RINDI et al. (2011) and ŠKALOuD \& Rindi (2013), respectively. The strains selected by previous authors as epitypes of different species are indicated by empty arrowheads. The strain F8B we propose as a new epitype for $K$. nitens is marked by the solid arrowhead. 
For phylogenetic analyses, the newly obtained $r b c \mathrm{~L}$ sequences were incorporated into previously aligned matrices (ŠKALOUD et al. 2014), and aligned by using ClustalW (THOMPSON et al. 1994) with MEGA version 6.0 (TAMURA et al. 2011). The $r b c \mathrm{~L}$ alignment had $596 \mathrm{bp}$ and is available on http://botany.natur.cuni.cz/algo/align/04_Klebsormidium. fas. The aligned data set was analyzed by using Maximum Parsimony (MP) analysis with PAUP 4.0b10 (SwOFForD 2002), Maximum Likelihood analysis (ML) with GARLI (ZwICKL 2006), and Bayesian analysis (BI) with MrBayes version 3.2.2 (RoNQUIST et al. 2012). The evolutionary model applied in ML and BI analyses was determined by using PAUP/MrModeltest 2.3 (Nylander 2004). The model selected under the Akaike Information Criterion was GTR + I $+\mathrm{G}$. The BI analysis was performed by using the priors set as default in MrBayes. The robustness of the tree topologies was assessed by bootstrapping the data set as described by ŠKALOUD \& RINDI (2013).

Morphological observations. To obtain a detailed morphological characterization of Klebsormidium isolates, the strains were regularly observed during the 3-month period of culturing, using an Olympus BX51 microscope (Olympus Corp., Tokyo, Japan) equipped with a differential interference contrast. In addition to observing the general growth habit, formation of $\mathrm{H}$-shaped pieces at cross walls, and reproductive features (shape of release aperture in lateral wall of zoosporangial cell and germination pattern of zoospores), cell dimensions were measured in detail in ImageJ software. For each strain, cell dimensions were measured on fresh, 4-week-old, exponentially growing cultures, as well as on nutrient-depleted, 3-month-old cultures. The average, minimal and maximal values were calculated from at least 30 replicates. Zoospore formation was induced by transferring the cultures to a $1 \%$ glucose solution, and keeping them in darkness at a temperature of about $10{ }^{\circ} \mathrm{C}$.

\section{Results}

In total, we isolated 5 and 18 unialgal Klebsormidium strains from the material collected in Strasbourg, France and Padua, Italy, respectively. The five Strasbourg strains were labelled as S201, S202, S203, S204, and S205. The Padua strains were isolated from material collected in six sampling sites: side of Basilica di Sant'Antonio (strains F1A, F1B, and F1C), and five sites in the Botanical Garden: crust on stony manufacture (strains F2A and F2B), concrete manufacture (strains F3A, F3B, F3C, F3D, and F3E), concrete margin of a pond (F7A), concrete side of a pond (F8A, $\mathrm{F} 8 \mathrm{~B}$, and $\mathrm{F} 8 \mathrm{C})$, and base of a statue $(\mathrm{F} 11 \mathrm{~A}, \mathrm{~F} 11 \mathrm{~B}$, F11C, and F11D). All isolated strains were subjected to subsequent molecular analyses.

\section{Molecular data}

Bayesian analysis of the $r b c \mathrm{~L}$ dataset (Fig. 1) resulted in the topology largely corresponding to the analyses published in several previous works (RINDI et al. 2011; ŠKALOUD \& RINDI 2013; ŠKALOUD et al. 2014). Our analysis resolved all superclades $(A-G)$ and lineages
(1-13) identified by RINDI et al. (2011) and ŠKALOUD \& RINDI (2013), respectively. All strains isolated from the sample collected in Strasbourg, France (S201, S202, S203, S204, and S205) were inferred within a single lineage, the superclade C sensu Rindi et al. (2011). The strains from Padua, Italy were inferred within three different clades. The vast majority of them (15 strains labelled F1A-C, F2A-B, F3A-E, F8B, F11A-D) were inferred as members of the clade E4 sensu Rindi et al. (2011), i.e. clade 12 sensu ŠKALOUd \& Rindi (2013). Strains F7A and F8A were inferred to belong to clade E2 sensu Rindi et al. (2011), i.e. clade 3 sensu ŠKALOUd \& Rindi (2013). Finally, the strain F8C was resolved as a member of clade E3 sensu RINDI et al. (2011), i.e. clade 7 sensu Škaloud \& Rindi (2013).

\section{Morphological data}

For the purpose of detailed morphological characterization of the dominant lineages found in Strasbourg and Padua, three Klebsormidium cultures were selected from a set of cultured strains belonging to clades $\mathrm{C}$ and E4, respectively. Strasbourg Klebsormidium was represented by strains S201, S202, and S203. Filaments were very long, with more than 1,000 cells per filament, without any tendency to fragmentation in older cultures. Cells were cylindrical, not constricted, 0.7-2.6 times as long as wide (Figs 2A-C). Cell dimensions differed among the strains (Table 1): cells of the strain S201 were generally wider $(7.4 \pm 0.7 \mathrm{~mm})$ and shorter $(9.6 \pm 3.6 \mathrm{~mm})$, whereas the strain S202 produced generally thinner $(6.3 \pm 0.7 \mathrm{~mm})$ and longer $(12.6 \pm 3.5 \mathrm{~mm})$ cells. In all strains, cell width gradually increased with the age of the cultures. The most distinctive difference was observed in the strain S201: the average cell width increased from $6.8 \pm 0.2 \mathrm{~mm}$ to $8.0 \pm 0.6 \mathrm{~mm}$ after two months in culture. In mature cultures, formation of $\mathrm{H}$-shaped pieces at cross walls was commonly observed in all strains (Fig. 2D). The release of zoospores was successfully induced in all observed strains. Whereas the release apertures in empty zoosporangial cell walls were distinct in the strain S202 (Fig. 2E), the remaining ones exhibited an indistinct margin of the apertures (Fig. 2F). In all strains, the zoospores generally germinated with a bipolar pattern (Fig. 2G).

For morphological characterization of Padua strains, we selected the isolates F1B, F3C and F8B, inferred within the predominant clade E4. The strains generally shared a common general morphology. Filaments were very long, with more than 1,000 cells per filament, without any tendency to fragmentation in older cultures (Figs 2H-J). Individual filaments were occasionally coiled together to form rope-like structures (Fig. 2J). Cells were cylindrical, not constricted, 0.81.9 times as long as wide (Figs $2 \mathrm{H}-\mathrm{I}$ ). Cell dimensions were comparable among the strains, with the exception of slightly wider cells in strain F8B (Table 1). In contrast to the Strasbourg isolates, the cell width gradually 

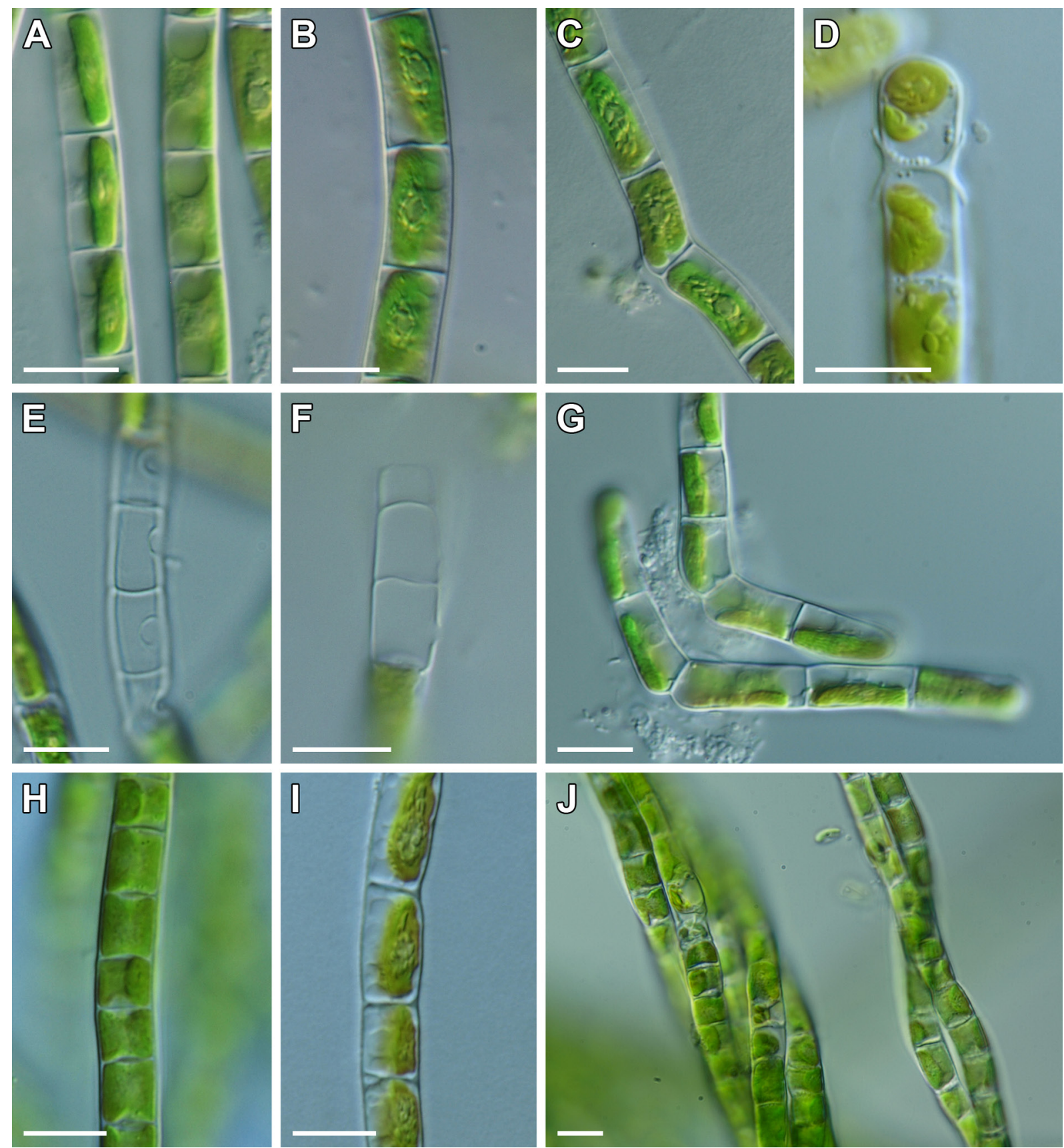

Fig. 2. Morphology of investigated Klebsormidium flaccidum and K. nitens strain: (A-G) K. flaccidum, (A) young filament (S202), (B) mature filament with conspicuous starch grains covering the pyrenoid (S201), (C) production of a mucilaginous attaching disc (S203), (D) few-celled filament with a distinct $\mathrm{H}$-shaped wall piece (S202), (E) empty zoosporangium with a distinct discharge pore (S202), (F) empty zoosporangium with an indistinct pore (S201), (G) young filaments grown after a bipolar germination of settled zoospores (S202); (H-J) K. nitens, (H) young filament with indistinct pyrenoids (F1B), (I) mature filament with conspicuous starch grains covering the pyrenoid (F3C), (J) rope-like strands of twisted filaments (F3C). Scale bar $10 \mathrm{~mm}$.

decreased in aging cultures. In all strains, the cell width decreased by $0.6-0.9 \mathrm{~mm}$ after two months of cultivation. Similarly, the average cell length increased by 2-3 mm. The formation of $\mathrm{H}-$ shaped cell wall pieces was never observed. In all cultures, we observed the occasional formation of spirally twisted filaments resulting in the production of rope-like strands of filaments (Fig. 2J). Despite several attempts, production of zoospores could not be induced.

\section{Discussion}

In the present study, we made collections of Klebsormidium from the type locality of Klebsormidium flaccidum (Strasbourg) and a locality that is the best candidate as putative type locality for $K$. nitens (Padua). Based on our observations and the original descriptions of the two species, we isolated some strains that we believe to correspond to the protologues of Ulothrix flac- 
cida and Ulothrix nitens of Kützing (KüTZING 1849). It is worth stressing that $K$. flaccidum and $K$. nitens are species of particular significance, and their correct taxonomic circumscription is critically important from several points of view. The phylogenetic position of these algae affects the classification of the entire order Klebsormidiales, a group that occupies a basal position in the streptophycean lineage (LEwIS \& McCourT 2004; LELIAERT et al. 2012) and is considered of great evolutionary and genomic interest (CIVÁŇ et al. 2014; Hori et al. 2014). Especially important in this regard is the identity of K. flaccidum, the type species of Klebsormidium. In molecular phylogenies, several strains corresponding morphologically to K. flaccidum occur in the clade that is sister to Interfilum (MikHailyuK et al. 2008; Rindi et al. 2008, 2011; Š KALOUD et al. 2014; RYŠÁNEK et al. 2015), whereas many other strains occur in separate clades. Since Klebsormidium is rendered paraphyletic by Interfilum, and K. flaccidum is the type species of the genus, the classification of Klebsormidium is dependent on which clade includes correctly typified K. flaccidum, and, ultimately, whether one or more segregate genera should be formed from other species of the genus. More generally, the identity of $K$. flaccidum and $K$. nitens is important in terms of biodiversity and biogeography of the microbial communities of terrestrial habitats. These species are reported among the most common green microalgae in these assemblages (ETTL \& GäRTNER 1995; LOKHORST 1996; LUKEŠOVÁ 2001; JOHN 2002; RINDI \& GUIRY 2004; UHER et al. 2005; ŠKaloud 2006; MikHailyuk 2008) and have been recorded virtually in every region in the world where terrestrial algae have been studied.

For these reasons, the unambiguous placement of $K$. flaccidum and $K$. nitens in molecular phylogenies is a problem of critical importance, as has been remarked in several recent studies (RINDI et al. 2011; ŠKalOUd \& Rindi 2013; ŠKaloud et al. 2014). In his monograph, LOKHORST (1996) designated lectotype specimens for Ulothrix flaccida (L 939.67-905) and $U$. nitens (L 939.67-828). Unfortunately, both materials consist of small tufts formed by a few filaments, for which detailed morphological observations and DNA extraction are impossible (Willem Prud'homme van Reine, personal communication). The only possible approach was therefore to select for both species epitype strains, using living material that can be sequenced and linked to molecular phylogenetic clades. The study of MikHAiLYUK et al. (2015) had the great merit of designating such epitypes and fixing the position of these species in the phylogeny of the Klebsormidiales. However, the epitypification of MikHaILYuk et al. (2015) was based on the characterizations of Klebsormidium flaccidum and K. nitens given by LoKHORST (1996), and neither of the epitype strains selected by these authors came from the type localities (the strain SAG 2307, epitype of $K$. flaccidum, was isolated from clay soil in a field of beets near Niederkruechten, Germany; the strain SAG 13.91, epitype of $K$. nitens, was isolated from soil at Tekoa, New Zealand). The choice of material obtained from the original type localities and habitats is a procedure strongly recommended for epitypification (Hyde \& Zhang 2008; Hughey \& Gabrielson 2012), as it maximizes the chances to obtain authentic material. In the case of the genus Klebsormidium we consider this aspect even more important, because several recent studies suggested that ecological preferences play a major role in the distribution and speciation patterns of this genus (ŠKKALOUD \& RiNDI 2013; ŠKALOUd et al. 2014; RYŠÁnEK et al. 2015). So, in this study we carefully looked for material corresponding to the original descriptions of Ulothrix flaccida and $U$. nitens in their type localities. We acknowledge that there cannot be the absolute certainty that the strains that we obtained are exactly the same algae used by KüTzING (1849) for the original descriptions; however, due to the impossibility of sequencing the lectotype specimens, this would be inevitably the case with any specimen selected as epitype. We believe that our strains, obtained from the original type localities and habitats, have the highest chances to represent the authentic Ulothrix flaccida and U. nitens.

For Klebsormidium flaccidum, three strains (S201, S202, S203) were isolated from a stony street in Strasbourg, the original habitat of the species ("Ad vias lapideas Argentorati: cl. A. Braun.”: KützING 1849: 349). The description of Ulothrix flaccida is (translated from Latin with the units of measurements converted to microns) "Ulothrix green, $6.45-7.52 \mu \mathrm{m}$ in diameter, with cells as long as wide or twice as long as wide, hyaline; nuclei of cells distant from each other". Though we observed a slight difference in cell dimensions between the three isolated strains (Table 1), their morphology conforms well to Kützing's description (although it is not certain what precisely Kützing meant by «nuclei cellularum distantibus», it may be that he was referring to the pyrenoids of the chloroplasts or to the coloured contents of the cells) and is also in good agreement with the concept of Klebsormidium flaccidum as generally established in the literature. This alga is reported as a species with filaments mostly long ( $>150$ cells), thin-walled cylindrical cells, slight constrictions between adjacent cells, chloroplast with smooth margin extending for the whole length of the cell and covering about a half of the lateral wall, and devoid of biseriate parts and false branches. Some disagreement exists in the literature about the range of width of the filaments: 6-9.5 $\mu \mathrm{m}$ in Hazen (1902); 5-8 $\mu \mathrm{m}$ in Mattox \& Bold (1962); 5-9 $\mu \mathrm{m}$ in Printz (1964); 5-14 $\mu \mathrm{m}$ in RAMANATHAN (1964) and JoHN (2002); 5.5-6 $\mu \mathrm{m}$ in FAROOQUI (1968); 5.5-7 $\mu \mathrm{m}$ in KomÁromy (1976); 5.6-7.4 $\mu \mathrm{m}$ in LOKHORST (1996); 6-9 $\mu \mathrm{m}$ in Š́KALOUD (2006). The dimensions of our strains (having average cell widths 6.3 $\pm 0.7 \mu \mathrm{m}, 7.0 \pm 0.5 \mu \mathrm{m}$, and $7.4 \pm 0.7 \mu \mathrm{m}$, respectively), however, are in the range of width given in Kützing's original description (1/350-1/300"', about 6.45-7.52 
$\mu \mathrm{m})$. All three strains isolated from the original habitat in Strasbourg were inferred in the superclade C sensu RINDI et al. (2011), and are genetically identical to the strain SAG 2307 proposed be represent the epitype of K. flaccidum (Mikhailyuk et al. 2015). Although the strain SAG 2307 was isolated from a sample collected $300 \mathrm{~km}$ far from the type locality (Niederkruechten, Germany), our findings corroborate the correct selection of this strain as epitype of $K$. flaccidum.

The unambiguous circumscription of $K$. nitens is more complicated than that of $K$. flaccidum, due to the fact that in the original description the type locality was not explicitly designated. KüTZING (1849) described Ulothrix nitens based on material collected and sent to him by Meneghini, named Hormidium nitens in the letter that Meneghini attached to the material (KÜTZING 1849: 349). The original description mentions that the alga was collected from flowerpots, mixed with Porphyridium purpureum (BORY) K.M. Drew et R. Ross ("in ollis cum Palmella cruenta"), but does not mention the locality. Giuseppe Meneghini (1811-1889) was an Italian professor of sciences and politician. In the course of his academic career, he was active in the universities of Padua (from 1835 to 1848) and Pisa (from 1849 to 1889); we therefore consider very likely that the collection that he sent to Kützing (and that was used for the description of Ulothrix nitens) was from either of these localities. Considering that Species algarum was published by Kützing in 1849 and that the original material of Ulothrix nitens must have been received by him sometime earlier, we consider more likely that Meneghini made the original collection in Padua, rather than in Pisa. The botanical garden of Padua is the oldest academic botanical garden in the world (founded in 1545 by the Venetian Republic) and still today is located in the original site of foundation. Meneghini must have made extensive use of it for his academic activity, so we consider it the most likely candidate as collection site of $U$. nitens. This is partly supported by Kuzing's remark about the habitat (on flowerpots, mixed with Porphyridium purpureum).

Consequently, we isolated in culture numerous strains of Klebsormidium from the botanical garden of Padua. Their $r b c \mathrm{~L}$ sequences placed nearly all of them in the clade 12 of ŠKALOUD \& RINDI (2013) (=clade E4 of Rindi et al. 2011). The morphology of these algae agrees well with the original description of the species. The protologue of Ulothrix nitens (translated from Latin with the units of measurements converted to microns) reports "Ulothrix green, with filaments exactly and densely parallel, forming an iridescent membrane when dry, $6.45 \mu \mathrm{m}$ wide; cells slightly longer than wide or as long as wide; gonidia (nuclei of cells) cylindrical appressed - on flowerpots with Palmella cruenta: collected by Meneghini". The strains of Klebsormidium that we collected in Padua occurred in small amounts in the field-collected samples and did not form the shiny films mentioned by KüTZING (1849). However, we collected several specimens from concrete surfaces, including flowerpots (strains F3A, F3B, F3C, F3D, and $\mathrm{F} 3 \mathrm{E}$ ), for which width of filaments and shape of the cells agree perfectly with the description (concerning gonidia, it is again difficult to understand what Kützing meant; since he mentions the cylindrical shape, we suppose that he might refer to the chloroplasts).

The taxonomic status of $K$. nitens has been questioned by many authors in the past. Indeed, the differences between $K$. nitens and $K$. flaccidum are rather tenuous and in some treatments the two species were not recognized as separate taxa (e.g., CHOdat 1902; FAROOQui 1968; EtTl \& GärTNER 1995). Most authors, however, distinguished them based mainly on the diameter of filaments (generally thinner in $K$. nitens) and the form of growth in liquid culture mainly as a superficial film (in K. nitens) or as a mass of submerged filaments (in K. flaccidum) (KLeBs 1896; PrINTZ 1964; LOKHORST 1996). LoKHORST (1996) reported also that the two species can be distinguished based on some features in culture (ease with which zoosporangia can be induced, shape of the release aperture of the zoosporangium, pattern of germination of zoospores). ŚKALOUD (2006), however, after an extensive culture investigation performed on 40 strains belonging to the $K$. flaccidum/ nitens complex, concluded that these characters in general were not tenable to separate species. Although some characters could be used to define strain clusters (cell width, aperture type of zoosporangia and microbiotope of habitat), clusters of strains created on the basis of one delimiting character did not correspond with clusters based on other characters (ŠKKALOUD 2006). Interestingly, the morphological circumscription of $K$. nitens has apparently changed over time, and significantly deviated from its original description. The taxon was originally described to have filaments $6.45 \mu \mathrm{m}$ wide (in the protologue, the dimensions were given in pre-metric French length units called lignes, as 1/350"'; KüTZING 1849). Later on, KLEBS (1896) defined K. nitens by having filaments 5.5-7.0 $\mu \mathrm{m}$ wide and his circumscription was then followed by numerous authors (HEERING 1914; Printz 1964; Starmach 1972). However, in the two most recent taxonomic treatments of the genus Klebsormidium, K. nitens was defined by having much thinner filaments. FAROoQUI (1968) characterized this alga as having filaments $5.0-5.6 \mu \mathrm{m}$ wide (although she hypothesized it to represent an ecophysiological morph of K. flaccidum). LoKHORST (1996) defined $K$. nitens with cell width 4.7-5.6(-6.5) $\mu \mathrm{m}$. MiKHAILYUK et al. (2015) followed Lokhorst's circumscription and designated the strain SAG 13.91 as epitype of this taxon. However, this strain has filaments $5.1 \pm 0.30 \mu \mathrm{m}$ wide (Š́KALOUD \& Rindi 2013), which clearly does not correspond to the original species description by KüTZING (1849). Additionally, the strain SAG 13.91 was isolated from New Zealand, therefore extremely far from the original sampling site, which (although with 
the uncertainties mentioned above) almost certainly is in Italy. We therefore conclude that the epitype of $K$. nitens selected by MikHAILYUK et al. (2015) most probably does not represent the authentic Ulothrix nitens described by KützING (1849). For this reason, in our opinion Klebsormidium nitens is a suitable candidate taxon for conservation based on a new epitypification. The new epitype would supersede the epitype selected by MikhaiLyuK et al. (2015) and should be a strain isolated from Italy, with morphology corresponding to the original protologue. We suggest our sample F1B (=culture CAUP J 306) would be an appropriate candidate as new epitype for this species.

As general conclusion, we would like to stress strongly the importance of an accurate, well-thought selection of epitype specimens/strains. Although this is true for all algae, it applies in particular to morphologically simple green microalgae, whose huge genetic and ecological diversity is being more and more unravelled. In the future, epitypes will become the essential reference for the definition of many species of morphologically simple algae; their selection should be taken very seriously and handled with great attention, always verifying that the morphology of the material selected agrees with the original protologue. All possible precautions should be taken to ensure that the epitype really corresponds to the alga of the original description; using material collected in the type locality and isolated from the original habitat will maximize the chance that this is accomplished. The careless and unwarranted selection of an epitype has the potential to create major nomenclatural problems and great confusion about the circumscription of a species; such confusion could be spread easily, especially in the case of species of great biotechnological interest, as it the case for some common microchlorophytes (HANNON et al. 2010; Wu et al. 2014). So far, epitypes have been designated only for a limited number of green microalgae (e.g., KRIENITZ et al. 2010; FučíkovÁ et al. 2013; AlLEWAERT et al. 2015) and many other species that have been described only on morphological basis are still waiting for the fulfilment of this procedure. We hope that epitypes selected by rigorous and accurate procedures that accord with the protologues will be soon available for many more species.

\section{ACKNOWLedgements}

We would like to thank Prof. Michael Guiry, National University of Ireland, Galway, for useful and stimulating discussion. The study was supported by a grant from the Charles University Science Foundation (GAUK No. 1544214).

\section{REFERENCES}

Agardh, C. A. (1824): Systema Algarum. - Berling, Lund. Allewaert, C.; Vanormelingen, P.; Pröschold, T.; Gómez, P.; GonZÁlez, M., BILCKe, G.; D’Hondt, S. \& VyverMAN, W. (2015): Species diversity in European Hae- matococcus pluvialis (Chlorophyceae, Volvocales). - Phycologia 54: 583-598.

Bischoff, H. \& Bold, H. C. (1963): Some soil algae from Enchanted Rock and related algal species. - Phycological Studies IV. Univ. Texas Publ. 6318: 1-95.

Bock, C.; Pröschold, T. \& Krienitz, L. (2011): Updating the genus Dictyosphaerium and description of Mucidosphaerium gen. nov. (Trebouxiophyceae) based on morphological and molecular data. - J. Phycol. 47: 638-652.

Buchheim, M. A.; Buchheim, J. A.; Carlson, T.; Braband, A.; Hepperle, D.; Krienitz, L.; Wolf, M. \& Hegewald, E. (2005): Phylogeny of the Hydrodictyaceae (Chlorophyceae): inferences from rDNA data. - J. Phycol. 41: 1039-1054.

Chodat, R. (1902): Algues vertes de la Suisse. Materiaux pour la Flore Cryptogamique Suisse, vol. 1, fasc. 3. - Wyss, Bern.

Civáñ, P.; Foster, P. G.; Embley, M. T.; Seneca, A. \& Cox, C. J. (2014): Analyses of charophyte chloroplast genomes help characterize the ancestral chloroplast genome of land plants. - Genome Biol. Evol. 6: 897-911.

De Toni, G. B. (1889): Sylloge algarum omnium hucusque cognitarum, vol. 1. Chlorophyceae. Patavii [Padua], Sumptibus auctoris.

EtTL, H. \& GäRTNER, G. (1995): Syllabus der Boden-, Luftund Flechtenalgen. - 721 pp., Stuttgart, Jena and New York: Gustav Fischer Verlag.

Farooqui, P.B. (1968): A note on the genus Chlorhormidium Fott (Ulotrichaceae). - Preslia 41:1-7.

FučíkovÁ, K.; Lewis; P. O. \& Lewis, L. A. (2014): Putting incertae sedis taxa in their place: a proposal for ten new families, and three new genera in Sphaeropleales (Chlorophyceae, Chlorophyta). - J. Phycol. 50: 14-25.

FučíkovÁ, K.; Fletchner, V., Lewis, L. A. (2013): Revision of the genus Bracteacoccus Tereg (Chlorophyceae, Chlorophyta) based on a phylogenetic approach. Nova Hedwigia 96: 15-59.

Guiry, M. D. \& Guiry, G. M. (2015): ALGAEBASE. Worldwide electronic publication, National University of Ireland, Galway. http://www.algaebase.org/ (accessed 02 Apr 2016).

Hannon, M.; Gimpel, J.; Tran, M.; Rasala, B. \& Mayfield, S. (2010): Biofuels from algae: challenges and potential. - Biofuels 1: 763-784.

HANSGIRG, A. (1886): Prodromus der Algenflora von Böhmen. Erster Theil enthaltend die Rhodophyceen, Phaeophyceen und einen Theil der Chlorophyceen. - Arch. Naturwis. Landesdurchforsch. Böhmen 5: 1-96.

HAzEn, T.E. (1902): The Ulotrichaceae and Chaetophoraceae of the United States. - Mem. Torrey Bot. Club 11: $135-250$.

HeEring, W. (1914): Chlorophyceae III. Ulotrichales, Microsporales, Oedogoniales. In: PAscher, A. (ed.): Die Süsswasserflora Deutschlands, Oesterreichs und der Schweiz, Heft 6. - pp. 1-250, Gustav Fischer, Jena.

Hepperle, D. (2004): SeqAssem. A sequence analysis tool, contig assembler and trace data visualization tool for molecular sequences. http://www.sequentix.de.

Hori, K.; Maruyama, F.; Fujisawa, T.; Togashi, T.; Yamamoto, N.; SeO, M.; Sato, S.; Yamada, T.; Mori, H.; TалIMA, N. et al. (2014): Klebsormidium flaccidum genome reveals primary factors for plant terrestrial 
adaptation. - Nature Communic. 5: 3978.

Hughey, J. R. \& Gabrielson, P. W. (2012): Comment on "Acquiring DNA sequence data from dried archival red algae (Florideophyceae) for the purpose of applying available names to contemporary genetic species: a critical assessment". - Botany 90: 191-203.

Huss, V. A. R.; Frank, C.; Hartmann, E. C.; Hirmer, M.; Kloboucek, A.; Seidel, B. M.; Wenzeler, P. \& KesSLER, E. (1999): Biochemical taxonomy and molecular phylogeny of the genus Chlorella sensu lato (Chlorophyta). - J. Phycol. 35: 587-598.

Hyde, K. D. \& Zhang, Y. (2008): Epitypification: should we epitypify? - J. Zehjiang Univ. Sci. B 9: 842-846.

John, D. M. (2002): Orders Chaetophorales, Klebsormidiales, Microsporales, Ulotrichales. - In: JoHN, D. M.; Whitton, B. A. \& BRook, A. J. (eds): The Freshwater Algal Flora of the British Isles. - pp. 433-468, Cambridge, Cambridge University Press.

Kaplan, F.; Lewis, L. A.; Wastian, J. \& Holzinger, A. (2012): Plasmolysis effects and osmotic potential of two phylogenetically distinct alpine strains of Klebsormidium (Streptophyta). - Protoplasma 249: 789-804.

Karsten, U.; Pröschold, T.; MikhailyuK, T. I. \& Holzinger, A. (2013). Photosynthetic performance of different genotypes of the green alga Klebsormidium sp. (Streptophyta) isolated from biological soil crusts of the Alps. - Algological Studies 142: 45-62.

KLeBS, G. A. (1896): Ueber Die Fortpflanzungs-Physiologie der niederen Organismen, der Protobionten. Specieller Theil. Die Bedingungen der Fortpflanzung bei einigen Algen und Pilzen. - Jena: Verlag von Gustav Fischer.

KomÁRomy, P. (1976): Studies on terrestrial Chlorhormidium (Kütz.) Fott species (Ulotrichales). - Ann. Hist. Nat. Mus. Nat. Hung. 68: 39-44.

Krienitz, L. \& Bock, C. (2012): Present state of the systematic of planktonic coccoid green algae of inland waters. - Hydrobiologia 698: 295-326.

Krienitz, L.; Bock, C.; Luo, W. \& Pröschold, T. (2010): Polyphyletic origin of the Dictyosphaerium morphotype within Chlorellaceae (Trebouxiophyceae). - J. Phycol. 46: 559-563.

Krienitz, L.; Huss, V. A. R. \& Bock, C. (2015): Chlorella: 125 years of the green survivalist. - Trends Plant Sci. 20: 67-69.

Kützing, F. T. (1843). Phycologia generalis oder Anatomie, Physiologie und Systemkunde der Tange. Mit 80 farbig gedruckten Tafeln, gezeichnet und gravirt vom Verfasser. - 458 pp., F. A. Brockhaus, Lipsiae [Leipzig].

Kützing, F. T. (1849): Species algarum. - 922 pp., F. A. Brockhaus, Lipsiae [Leipzig].

Leliaert, F.; Smith, D. R.; Moreau, H.; Herron, M.; VerBruggen, H.; Delwiche, C. F. \& De Clerck, O. (2012): Phylogeny and molecular evolution of green algae. - Crit. Rev. Plant Sci. 31: 1-46.

Lewis, L. A. \& McCourt, R. M. (2004): Green algae and the origin of land plants. - Am. J. Bot. 91: 1535-1556.

Linnaeus, C. V. (1753): Species plantarum. Vol. II. - Stockholm, Sweden.

Linnaeus, C. V. (1759): Systema naturae per regna tria naturae. Vol. II. - Stockholm, Sweden.

LokHorst, G. M. (1996): Comparative taxonomic studies on the genus Klebsormidium (Charophyceae) in Europe.
In: Julich, W. (ed.): Cryptogamic Studies vol. 5. pp. 1-132, Stuttgart: Gustav Fischer.

LukeŠovÁ, A. (2001): Soil algae in brown coal and lignite post-mining areas in central Europe (Czech Republic and Germany). - Restor. Ecology 9: 341-350.

Mattox, K.R. \& Bold, H.C. (1962): Phycological Studies III. The taxonomy of certain ulotrichacean algae. Univ. Texas Publ. 6222: 1-67.

Mikhailyuk, T. I. (2008): Terrestrial lithophytic algae in a granite canyon of the Teteriv River (Ukraine). - Biologia 63: 824-830.

Mikhailyuk, T. I.; Sluiman, H. J.; Massalski, A.; Mudimu, O.; Demchenko, E. M.; Kondratyuk, S. Y. \& Friedl, T. (2008): New streptophyte green algae from terrestrial habitats and an assessment of the genus Interfilum (Klebsormidiophyceae, Streptophyta). - J. Phycol. 44: 1586-1603.

Mikhailyuk, T. I.; Holzinger, A.; Massalski, A. \& Karsten, U. (2014): Morphology and ultrastructure of Interfilum and Klebsormidium (Klebsormidiales, Streptophyta) with special reference to cell division and thallus formation. - Eur. J. Phycol. 49: 395-412.

Mikhailyuk, T. I.; Glaser, K.; Holzinger, A. \& Karsten, U. (2015): Biodiversity of Klebsormidium (Streptophyta) from Alpine biological soil crusts (Alps, Tyrol, Austria, and Italy). - J. Phycol. 51: 750-767.

Moniz, M. B. J.; Rindi, F.; Novis, P. M.; BRoAdy, P. A. \& GuiRY, M. D. (2012): Molecular phylogeny of Antarctic Prasiola reveals extreme cryptic diversity. - J. Phycol. 48: 940-955.

NÄGELI, C. (1849): Gattungen einzelliger Algen, physiologisch und systematisch bearbeitet. - N. Denkschr. Allg. Schweiz. Gesell. Ges. Naturwiss. 10: 1-139.

Novis, P. M. (2006): Taxonomy of Klebsormidium (Klebsormidiales, Charophyceae) in New Zealand streams and the significance of low- $\mathrm{pH}$ habitats. - Phycologia 45: 293-301.

Nylander, J. A. A. (2004): MrModeltest v2. Program distributed by the author. Evolutionary Biology Centre, Uppsala University. http://www.abc.se/ nylander/ (accessed 12 May 2015).

PrintZ, H. (1964): Die Chaetophoralen der Binnengewässer. Eine systematische übersicht. - Hydrobiologia 24: $1-376$.

RABENHORST, L. (1868): Flora europaea algarum aquae dulcis et submarinae. Sectio III. Algae chlorophyllophyceas, melanophyceas et rhodophyceas complectens. - 461 pp., Apud Eduardum Kummerum, Lipsiae [Leipzig].

Ramanathan, K. R. (1964). Ulotrichales. - 188 pp., Indian Council of Agricultural Research, New Delhi, India.

RINDI F. (2011): Terrestrial green algae: systematics, biogeography and expected responses to climate change. - In: Hodkinson, T.; Jones, S.; Waldren, S. \& ParNELL, J. (eds): Climate Change, Ecology and Systematics. - pp. 201-227, Systematics Association Special Volume. Cambridge: Cambridge University Press.

Rindi, F. \& GuirY, M. D. (2004): Composition and spatial variability of terrestrial algal assemblages occurring at the bases of urban walls in Europe. - Phycologia 43: $225-235$

Rindi, F.; Guiry, M. D. \& Lopez-Bautista, J. M. (2008): Distribution, morphology and phylogeny of Klebsormidium (Klebsormidiales, Charophyceae) in urban 
environments in Europe. - J. Phycol. 44: 1529-1540.

Rindi, F.; Lam, D. W. \& LóPez-Bautista, J. M. (2009): Phylogenetic relationships and species circumscription in Trentepohlia and Printzina (Trentepohliales, Chlorophyta). - Mol. Phylogen. Evol. 52: 329-339.

Rindi, F.; Mikhailyuk, T. I.; Sluiman, H. J.; Friedl, T. \& López-Bautista, J. M. (2011): Phylogenetic relationships in Interfilum and Klebsormidium (Klebsormidiophyceae, Streptophyta). - Mol. Phylogen. Evol. 58: 218-231.

Ronquist, F.; Teslenko, M.; van der Mark, P.; Ayres, D.; Darling, A.; Höhna, S.; Larget, B.; Liu, L.; SuchaRD, M. A. \& Huelsenbeck, J. P. (2012): MrBayes 3.2: efficient Bayesian phylogenetic inference and model choice across a large model space. - Syst. Biol. 61: 539-542.

RYšÁneK, D.; HrČKovÁ, K. \& ŠKaloud, P. (2015): Global ubiquity and local endemism of free-living terrestrial protists: phylogeographic assessment of the streptophyte alga Klebsormidium. - Environ. Microbiol. 17: 689-698.

RYŠÁNEK, D.; Elster, J.; KovÁČIK, L.; \& ŠKALOUd, P. (2016a): Diversity and dispersal capacities of a terrestrial algal genus Klebsormidium (Streptophyta) in polar regions. - FEMS Microbiol. Ecol. 92: fnw039.

RYŠÁneK, D.; Holzinger, A.; \& ŠKaloud, P. (2016b): Influnence of substrate and $\mathrm{pH}$ on the diversity of the aeroterrestrial alga Klebsormidium (Klebsormidiales, Streptophyta): a potentially important factor for sympatric speciation. - Phycologia 55: 347-358.

Silva, P. C.; Mattox, K. R. \& Blackwell, W. H. (1972): The generic name Hormidium as applied to green algae. Taxon 21: 639-645.

ŠKALOUD, P. (2006): Variation and taxonomic significance of some morphological features in European strains of Klebsormidium. - Nova Hedwigia 83: 533-550.

ŠKaloud, P. \& PeKsA, O. (2010): Evolutionary inferences based on ITS rDNA and actin sequences reveal extensive diversity of the common lichen alga Asterochloris (Trebouxiophyceae, Chlorophyta). - Mol. Phylogen. Evol. 54: 36-46.

ŠKaloud, P. \& Rindi, F. (2013): Ecological differentiation of cryptic species within an asexual protist morphospecies: a case study of filamentous green alga Klebsormidium (Streptophyta). - J. Eukar. Microbiol. 60: $350-362$.
ŠKaloud, P.; LukeŠová, A.; Malavasi, V.; RYšÁneK, D.; HrČKovÁ, K. \& RINDI F. (2014): Molecular evidence for the polyphyletic origin of low $\mathrm{pH}$ adaptation in the genus Klebsormidium (Klebsormidiophyceae, Streptophyta). - Plant Ecol. Evol. 147: 333-345.

Škaloud, P.; Steinová, J.; К̌idiká, T. \& Peksa, O. (2015): Assembling the challenging puzzle of algal biodiversity: species delimitation within the genus Asterochloris (Trebouxiophyceae, Chlorophyta). - J. Phycol. 51: 507-527.

Starmach, K. (1972): Chlorophyta III. Zelenice nitkowate. - In: Starmach, K. (ed.): Flora słodkowodna Polski 10. - 750 pp., PWN, Warszawa \& Krakow.

Swofford, D. L. (2002): PAUP*. Phylogenetic Analysis Using Parsimony (*and Other Methods). Version 4. Sinauer Associates, Sunderland, Massachusetts.

Tamura, K.; Peterson, D.; Peterson, N.; Stecher, G.; Nei, M. \& Kumar, S. (2011): MEGA5: Molecular evolutionary genetics analysis using maximum likelihood, evolutionary distance, and maximum parsimony methods. - Mol. Biol. Evol. 28: 2731-2739.

Thompson, J. D.; Higgins, D. G. \& Gibson, T. J. (1994): CLUSTAL W: improving sensitivity of progressive multiple sequence alignment through sequence weighting, position 86 specific gap penalties, and weight matrix choice. - Nucl. Acids Res. 22: 46734680.

Uher, B.; Aboal, M. \& KovÁČIK, L. (2005): Epilithic and chasmoendolithic phycoflora of monuments and buildings in South-Eastern Spain. - Cryptogamie, Algol. 26: 275-308.

VerbrugGen, H. (2014): Morphological complexity, plasticity and species diagnosability in the application of old species names in DNA-based taxonomies. - J. Phycol. 50: 26-31.

Wu, Y.; Hu, H.; Yu, Y.; Zhang, T.; Zhu, S.; ZhuanG, L.; Zhang, X. \& Lu Y. (2014): Microalgal species for sustainable biomass/lipid production using wastewater as resource: a review. - Ren. Sust. En. Rev. 33: $675-688$.

ZwICKL, D. J. (2006): Genetic algorithm approaches for the phylogenetic analysis of large biological sequence datasets under the maximum likelihood criterion. Dissertation, University of Texas at Austin, Austin, U.S.A.

(C) Czech Phycological Society (2017)

Received April 15, 2016

Accepted June 6, 2016 